\title{
'WALKING ON EGGSHELLS TO NOT OFFEND PEOPLE': EXPERIENCES OF SAME-SEX STUDENT COUPLES AT A SOUTH AFRICAN UNIVERSITY
}

\author{
E. Lesch* \\ e-mail: el5@sun.ac.za
}

\section{S. Brits*}

e-mail:16100026@sun.ac.za

\section{N. T. Naidoo*}

e-mail: 18836674@sun.ac.za

*Psychology Department

Stellenbosch University

Stellenbosch, South Africa

\section{ABSTRACT}

Rules and expectations for appropriate public couple behaviour on university campuses are predominantly heteronormative and marginalise people with other sexual orientations. Such environments pose specific challenges to same-sex couples with regards to everyday open living and enjoyment of their romantic relationships. Our study sought to explore the experiences of same-sex student couples in negotiating public campus life at a South African university. We interviewed six couples and used thematic analysis to analyse the data. We found that the participating couples experienced the campus as an evolving and ambiguous environment with both safe and unsafe public spaces. As a result, couples consistently and consciously monitored their social environments and regulated their public couple behaviour to avoid negative experiences. We conclude the article with suggestions as to how university management can assist in cultivating a more supporting campus environment for same-sex couples.

Keywords: same-sex couples, university students, couples' experiences, public spaces, heteronormativity, South Africa

\section{INTRODUCTION}

South African research indicates that the majority of South Africans view lesbian, gay, bisexual and transgender (LGBT) ${ }^{1}$ individuals and same-sex relationships as unacceptable (Roberts and Reddy 2008, 10; Pew Research Center 2013, 3; Mwaba 2009; Arndt 2004). Although research (e.g., Lambert, Ventura, Hall and Cluse-Tolar 2006) suggests that higher education impacts positively on attitudes to LGBT people, local research shows that many South African students South African Journal of Higher Education http://dx.doi.org/10.20853/31-4-893 
still hold negative attitudes towards LGBT people. For example, Mwaba $(2009,803)$ found that 44 per cent of the university students in his study believed that gay and lesbian individuals should not be socially accepted in South Africa. Butler, Alpaslan, Strümpher and Astbury $(2003,18)$ also argue that South African educational institutions continue to reproduce patterns of heterosexism.

Homosexual behavior is often tolerated if it is curtailed to so-called 'private spaces', e.g. in private homes, but tends to incite disapproval and negative attention when displayed in spaces such as streets, shops and parks that are commonly perceived as 'public spaces' (Hubbard 2001; Brickell 2000, 164). A critical engagement with the notion of public spaces has been the focus of a substantial body of literature specifically in the human geography field. Although these scholars draw from various theories (e.g. those of Erving Goffmann and Judith Butler) there is consensus that space is never neutral (Gregson and Rose 2000, 433-434). Furthermore, there is agreement that although the separation between private and public spaces is fluid and depend on context, this separation has very real implications for human social behavior as these spaces have implicit and/or explicit codes of conduct that determine acceptable behavior in them (Brickell 2000; Ferreira and Salvador 2015, 954-956). 'Public spaces' are contended to be constructed or produced around implicitly heteronormative codes of conduct. These codes are institutionalized and normalized to such an extent in these spaces that it is not recognized as such, whilst, in contrast, homosexual behavior is particularly noticeable if it occurs. Same-sex couples therefore often abstain from or modify public displays of affection. Public exhibition of same-sex couplehood, however, could serve as important social and political transformative acts in that it contests implicit dominant heteronormative assumptions (Brickell 2000, 165; Ferreira and Salvador 2015, 954-956; Hubbard 2001, 5153).

Earlier studies conducted at the university of study indicate that many LGBT students attending this university experienced the campus environment as homophobic and hostile, and hid their sexual orientation for fear of discrimination and victimisation (October 2006, 94; Graziano 2004). In Graziano’s (2004, 280) study, gay students shared incidents of victimisation that were reported to but not followed up by university management. An incident, where the independent student newspaper published a front-page photo of a gay couple kissing in August 2010, further demonstrates the contentious student environment regarding the acceptance of same-sex romantic relationships on this campus. The picture turned out to be controversial and was met with mixed responses. Many students found it offensive and even disgusting while others, mostly women, supported the newspaper's decision to publish the picture (Evans 2010). 
These results suggest an ambiguous campus environment in which intolerance and negative attitudes towards LGBT individuals and same-sex relationships still prevail. Same-sex romantic partners are likely to find it challenging to meet potential romantic partners, and to openly and visibly form and conduct a romantic bond in such a socially disapproving environment (Lehmiller and Agnew 2006, 48; Mohr and Daly 2008, 992).

Challenges to openly forming and conducting romantic relationships are specifically important for university students as the formation of romantic relationships is seen as a critical psychosocial task in their developmental stage of young adulthood. Furthermore, being in a romantic relationship can function as an important resource as it provides social support and has a positive effect on self-esteem and feelings of belonging (Mohr and Daly 2008, 991; Collins 2003, 15). Despite the importance of romantic relationships for young adult LGBT students, most research on LGBT students' experiences in higher education contexts has been conducted in the global north and focus on the individual student's experience. We therefore know little of how South African same-sex student couples experience and navigate heteronormative campus environments. Our study addressed this gap and aimed to explore gay and lesbian couples' experiences of the everyday living of their romantic relationships in public spaces (e.g. lecture halls, departments and residences) on one South African university campus.

\section{A BRIEF REVIEW OF THE LITERATURE RELEVANT TO SAME-SEX COUPLES' EXPERIENCES ON UNIVERSITY CAMPUSES}

Globally, attitudes towards LGBT individuals and same-sex relationships have become increasingly more accepting, although active opposition against equal rights for these individuals still exist (Camilleri and Ryan 2006; Ellis 2009; Avery, Chase, Johansson, Litvak, Montero and Wydra 2007). Research, however, indicates that acceptance of same-sex relationships varies across social contexts, e.g., countries and faculties. For example, Camilleri and Ryan (2006) found that Australian social work students were accepting towards lesbians, gay men and same-sex relationships while Gelbal and Duyan (2006) found that negative attitudes towards lesbian and gay people prevailed among Turkish university students. Ellis, Kitzinger, and Wilkonson (2003) found that British psychology students mostly held positive attitudes towards lesbian and gay people, but the student sample as a whole did not support lesbian and gay human rights (Ellis, Kitzinger and Wilkonson 2003). More liberal attitudes and interpersonal contact with lesbian and gay people have been shown to correlate with positive attitudes towards homosexual people and have therefore been used to explain these differences across social contexts (Camilleri and Ryan 2006; Gelbal and Duyan 2006). 
Gender differences have been found with regards to attitudes and responses to lesbian and gay people. Arndt (2004), for example, found a high prevalence of negative attitudes towards lesbian and gay people, especially amongst South African male students and conservative religious individuals (Arndt 2004, 73). Arndt (2004, 72) also compared her South African findings to a North American student sample and concluded that the South African female students had less negative attitudes towards lesbians and gay men than their United States counterparts, while South African male students had more negative attitudes towards lesbians and gay men than the male students in the United States sample. Mongie (2008, 80), too, found gender differences in his study at our university of focus, with 57 per cent of his male student sample holding homophobic related beliefs, in comparison with only 24 per cent of the female student sample.

Heteronormative gender belief systems and norms are argued to explain such gender differences towards same-sex relationships (Davies 2004, 265; Glick, Gangl, Gibb, Klumpner and Weinberg 2007, 57). Gay men and lesbian women, especially gender non-conforming gay men, represent a violation of what men and women are supposed to be, and therefore rejected on this basis (Kite 2001, 223). Ironically, it seems like gender non-conforming gay men and lesbian women may not only suffer from stigmatisation from outside the LGBT community but within it as well (Taywaditep 2002, 7).

LGBT students' campus experiences range from covert to overt discrimination and victimisation in campus environments. Rankin $(2003,4)$ found that 36 per cent of the American LGBT undergraduate students in his sample had experienced discrimination and harassment within the last year, the most common form of harassment reported was derogatory remarks. Another study conducted in the United States found that LGBT students perceived their campus environment as positive, although 53 per cent had experienced unfair treatment from fellow students (Tetreault, Fette, Meidlinger and Hope 2013, 953). In a British LGBT student sample, Ellis (2009, 730) found that 23.4 per cent had experienced homophobic related discrimination of which derogatory remarks comprised 77.9 per cent, direct or indirect verbal harassment 47.1 per cent, and threats of a physical nature 26.5 per cent. These forms of discrimination mostly occurred in public spaces, and were perpetrated by other students (Ellis 2009, 730). Even though the evidence suggests that actual discrimination against LGBT individuals was widespread, most of the participants thought that anti-LGBT attitudes were prevalent to a little/very little extent (Ellis 2009).

International research (e.g. Killelea McEntarfer 2011, 313; Ellis 2009; Blackwell, Ricks 
and Dziegielewski 2005) suggest that it is common for LGBT people to receive hostile responses from management structures at university or workplace, organisational settings, as well as religious societies. Similarly, Butler et al. (2008) found that South African secondary and tertiary students experienced harassment, rejection and isolation not only from fellow students but also from school administrators and teachers. October (2006) found at our university of study that LGBT students experienced the campus environment as homophobic and attributed this to traditional patriarchal gender roles (October 2006, 119). Same sex couples may therefore feel pressured to conceal their sexual orientation, romantic and/or sexual relationships in order to avoid harassment and discrimination (Rankin 2005, 18; Graziano 2004; Rostosky, Riggle, Gray and Hatton 2007, 286). Hill (2006, 10) and Ellis (2009, 727) therefore argue that educational institutions should implement prejudice reduction strategies related to sexual identity, sexual orientation and gender identity at a management level. These include educating students and employees in management positions about LGBT issues, and enforcing LGBT inclusivity by behavioural protection such as disciplinary action against those violating LGBT policies of inclusivity.

\section{THEORETICAL FRAMEWORK}

Our research was informed by a feminist social constructionist perspective. Broadly, feminist thought highlights that the privileging of heteronormativity and hegemonic masculinity in most societies impacts negatively on people's lives (Haralambos and Holborn 2008). It specifically draws attention to gender inequality, and the unequal distribution of power (Rhode 1990; Connell and Messerschmidt 2005) as articulated by Moya (2001, 471): 'as long as our world is hierarchically organized along enduring relations of domination, people occupying different locations will tend to experience the world in systematically different ways'. Feminism therefore aims to problematise taken for granted assumptions such as heteronormativity, in order to promote the empowerment of marginalised groups and to foster equality (Haralambos and Holborn 2008). It further aspires to recognise and voice the misrepresented experiences of the subordinate and marginalised groups (Connolly 2006). LGBT individuals are seen as a marginalised and oppressed group in a predominantly heteronormative society. This feminist informed study had as its objective to explore the subjective experiences of lesbian and gay couples of living their relationships in public campus spaces. In this exploration we were sensitised to the way in which LGBT individuals have internalised homophobia or accepted the negative societal attitudes and assumptions concerning same-sex attractions, as well as the ways in which LGBT individuals challenge these negative heteronormative views (Szymanski 2005). 


\section{METHOD}

\section{Research design}

A qualitative design was best suited to our feminist informed objective to explore the subjective experiences of same sex couples. Qualitative research aims to explore a small number of people's personal experiences in their own specific social contexts. It generates rich and textured data that allows the researcher to describe and interpret the various ways in which people experience and understand their world (Willig 2013).

\section{Research participants}

Three gay and three lesbian, 'white' couples volunteered to participate in the study. Using the pseudonyms which participants selected for themselves, the participant details are presented in Table 1 below:

Table 1: Participants

\begin{tabular}{|c|c|c|c|c|}
\hline Name & Sex & Age & Sexual orientation & $\begin{array}{l}\text { Relationship } \\
\text { duration }\end{array}$ \\
\hline Allison & Female & 22 & Lesbian & \multirow{2}{*}{24 months } \\
\hline Michelle & Female & 24 & Lesbian & \\
\hline Alex & Female & 20 & Lesbian & \multirow{2}{*}{18 months } \\
\hline Piper & Female & 21 & Lesbian & \\
\hline Gerhard & Male & 28 & Gay & \multirow{2}{*}{30 months } \\
\hline Jaco & Male & 22 & Gay & \\
\hline David & Male & 24 & Gay & \multirow{2}{*}{8 months } \\
\hline Bob & Male & 25 & Gay & \\
\hline Svedlana & Female & 20 & Lesbian & \multirow{2}{*}{7 months } \\
\hline Nadine & Female & 26 & Pansexual & \\
\hline Max & Male & 24 & Gay & \multirow{2}{*}{20 months } \\
\hline James & Male & 26 & Gay & \\
\hline
\end{tabular}

\section{Data collection procedure}

Before the study was undertaken, we obtained institutional permission as well as ethical clearance from the relevant University bodies.

We did not know the demographic profile of this student group and could not locate institutional information about them, e.g. number, ethnicity, and gender. This highlights important institutional knowledge limitations that we will discuss at the end of the article. Furthermore, same-sex couples were not very visible in and around campus at Stellenbosch University and recruitment of participants therefore posed a challenge. As snowball sampling has been found effective in such circumstances (Butler et al. 2008), we used this sampling 
technique. The first phase of the recruitment entailed that an invitation letter was posted on the student LGBT society's Facebook page to introduce the study and invite same-sex couples to participate. Through this invitation letter, we recruited a first couple who set our snowball recruitment process in motion as they encouraged other couples to participate. These couples, in their turn, also urged further couples to participate. There were no incentives offered to take part in the research. The snowball sampling process resulted in a limited relatively homogenous group of senior, white participants. Their experiences on campus very likely do not represent the experiences of black lesbian and gay students at Stellenbosch University as research indicates that LGBT students from different social contexts may have very different experiences (Longerbeam, Inkelas, Johnson and Lee 2007).

We used semi-structured interviews to explore the experiences of the participating couples. The interviews with couples were conducted by two graduate students in Psychology and consisted of a series of open-ended questions which offered departure points for exploring a specific couple's experiences (Bryman 2008). As we were specifically interested in the couple narrative and the partners' joint experience of being a couple on campus, the couples were interviewed conjointly (Eisikovits and Koren 2010). We are aware, however, that the resultant accounts were shaped by the dynamics of the joint interviews and that they might not accurately reflect each partner's individual perspective or experience (Mellor, Slaymaker and Cleland 2013). On reflection, it may have provided more comprehensive information about each couple's experiences if we had combined the joint interviews with subsequent individual interviews with each partner to obtain such additional perspectives (Mellor, Slaymaker and Cleland 2013).

The interviewers were trained and debriefed throughout the interview process by the first author, an experienced qualitative researcher. This process involved the interviewers listening to, transcribing and discussing each completed interview with each other and the first author with the view to honing their interviewing skills and to identifying further topics of inquiry to be pursued and clarified in subsequent interviews. All of the participants were keen to share their experiences of being a same-sex couple. They responded and elaborated comfortably in response to interview questions, and we were therefore able to collect rich material. The average length of the interviews was approximately 60 minutes. We concluded data collection when we determined that new interviews did not produce new themes or ideas.

\section{Data analysis}


Braun and Clarke's (2006; 2013) six-phase thematic analysis method was used to analyse the data. The first phase entailed that we familiarise ourselves with the data by listening to the audio recordings of the interviews as well as reading the transcribed interviews to get initial ideas of the content which might be relevant to the research question (Braun and Clarke 2006). In the second phase we systematically analysed the data by using line-by-line coding to capture the content of the data. In this coding we stayed close to the original data and the expressed meaning of the participants. As a parallel process, we also made notes of our own interpretations. The third phase of thematic analysis involved that we search for and identify possible themes. Fourthly, we reviewed these themes in order to establish whether it best captured our interview material. In the fifth and sixth phases of our thematic analysis process, we named and defined the themes, and documented each theme and its illustrating quotes.

\section{Trustworthiness of the study}

Due to space restrictions, we cannot provide an extensive discussion of trustworthiness issues. It must therefore suffice to highlight the mechanisms which we implemented to improve the dependability and credibility of our research. Firstly, we transcribed and reviewed each interview before proceeding with the next interview. This procedure assisted us in continually reviewing and refining our interviewing style and questions. It also allowed us to follow up on themes in later interviews which we identified in earlier interviews to ascertain its veracity. After the completion of the interviews, each of the three authors analysed the data separately. We then met and utilised the three separate analyses to create a synthesised analysis which utilised both the similarities and differences in the separate analyses. We were also aware of and reflected on how our own heterosexual orientations might influence our understanding and response to our participants' experiences. One of the themes which stood out in this regard was our growing awareness and empathy of the contrast between our own student experiences as heterosexual people and those of the participants. In our own campus experiences heterosexual romantic relationships were taken for granted, encouraged and expected in so many visible and invisible ways so that it was never necessary to think about how people would respond to one as part of a heterosexual couple. Conversely, the same-sex couples in our study could not and did not take for granted, nor expected, support and acceptance for their relationships.

\section{RESULTS}

In this section we present and discuss two overarching themes which capture the participant couples' experiences on campus. We tried to insert as many relevant couple quotes as space 
restrictions allowed to foreground the participants' voices, as well as utilising relevant literature where applicable.

\section{'The pink street': An ambiguous campus environment}

Overall, our impression was that all the participants were mindful and reflective about the influence of their own preconceived ideas regarding their experience and interpretations of others' responses to them. They were careful not to over-interpret or attribute their experiences of others' reactions to homonegativity. Importantly, they tended to dismiss smaller acts of possible homonegativity as long as these were not accompanied by overtly negative behaviour. This is illustrated by the following excerpt from the interview with Svedlana and Nadine:

Svedlana: The first time ever that a friend of ours and her girlfriend decided to finally hold hands ... and it was such a big moment for her. Um, there was a guy a floor above them or something and he literally spat on them. That's horrifying, we are lucky in that people haven't done that to us.

Nadine: The most that might happen when we are together, and it's not anything serious, is people sort of look as they walk past. But that could be for anything. I could be having a bad hair day. It's not necessarily because it's us close together.

Accordingly, many of the participants described the campus environment as 'open-minded', 'gay friendly' and 'accepting'. Allison stated that they had 'never really been confronted', while Jaco thought that other students' responses to his relationship was 'average' and 'normal'. David said that he was 'pleasantly surprised with how the campus environment was much more open than high school'. A more detailed look at their accounts, however, suggests a much more complex and ambiguous campus environment with campus spaces rarely perceived or experienced as completely 'safe', but as more or less safe. The various environments which we identified in the data, are discussed below.

\section{(i) Faculty environments}

Similar to the findings in other studies (e.g., Hopwood and Connors 2002) the participants perceived and/or experienced the Arts and Social Sciences environments as providing accepting and safe spaces as opposed to other faculties. Within an ambiguous campus environment, David and Bob had very real experiences of gay camaraderie and friendliness in front of the Arts and Social Sciences building:

David: $\quad$ There is a sort of conservative edge most of the time and makes it difficult to know which environment you are not safe .... My happiest memories are ones of standing 
outside the BA talking to people. Um, and just having fat chats about life, love and everything else. And I think that's where I always felt most comfortable. If I can pinpoint a specific location it would probably be outside the BA building.

Bob: $\quad$ Yeah, the BA is like the watering hole for social interaction.

Gerhard, a Natural Sciences student, referred to the street which mostly houses the Arts and Social Sciences departments as the 'pink street'. He perceived the Arts and Social Sciences contexts to be more accepting due to the visibility of gay students in that environment:

Gerhard: Different faculties react differently. I think if Jaco and I walk around BA we're both fine, that's just because, well BA and drama, we're fine because there's more gay students there or more publicly out students. In my faculty, sciences, there are but not a lot. I don't think engineering shows a lot at all ... I just think if we were to let's say hold hands and walk down the street here ('the pink street') I think the majority of students wouldn't care, but as we go more north to different faculties. Not science, science really wouldn't care, because science usually they are the atheists, the liberals and what-not. But when we go to I think more business or more mathematics or probably maybe law even then people would stare.

Allison and Michelle, both engineering students, talked about having their 'guard up' when they negotiated the general engineering environment. Allison said that 'my guard is super high with civil engineers' and perceived that group as 'very homophobic people'. Michelle experienced her own department of engineering as a haven in the broader engineering faculty:

Michelle: I would say my guard is down pretty much in my own department of engineering .... You need to swipe in with a card to get access so basically no, it's like a mini family. So I would pretty much say my guard is down there.

\section{(ii) University residences}

University residences were generally perceived as unwelcoming spaces for LGBT people. For example, Bob and David never considered living in a university residence due to this perception. Those of our participants who had experiences of living in residences indeed indicated that residence life presented challenges for same-sex couples. Alex and Piper recounted hurtful experiences regarding their attendance of a residence dance. In the account below, they highlighted the unfairness of the complaints about their demonstrations of affection by comparing their couple behaviour with the blatant behaviour of a heterosexual girl at the same dance:

Alex: $\quad$ She was my date, my plus one, you know? I had to pay extra to have her there type. And we were, actually, we weren't even that affectionate because it was still so early like, we were more affectionate than we were in the beginning, but it wasn't, like we 
weren't overbearing in the slightest. And we held hands and I think we pecked. One of my friends who was there as well actually, she was so trashed and she was trying to get into the pants of her date. So you can imagine what she was like. And the two of us like were at the complete opposite end of the spectrum like, and then what was it? Like a week later or whatever. There was a complaint .... Yes the housemother or whatever said that she needed to talk to me about something. Uhm, and then obviously like, panic attack, and then I asked am I in trouble or whatever, and she said no she wanted to talk to me about my relationship with Piper. And I was like, Ok. What's happening here? And apparently someone, anonymously, lodged a complaint against the two of us saying that we ... [Piper interjects]: were too affectionate. [Alex continues]: Ja, we were too affectionate at the dance and apparently, oh they complained because I had you in my room.

Jaco was a resident in a male university residence that is often perceived as a 'very masculine res'. Although his account clearly indicated that he was aware of nuanced discrimination, he still said: 'I was treated like everyone else. Except for, you know, you have some awkward situations with this homosocial kind of intimacy where people .... We didn't share showers, so we avoided stuff like that. And running around naked and stuff like that was a little bit more awkward.' His and Gerhard's experience of attending a residence dance was as follows:

Gerhard: I was from outside of res, I was scared shitless to beyond words. Because I was walking into one of the predominantly very masculine male res'es. And all around me are men I don't know from a bar of soap .... The dance itself, there were some second years who looked at us. Again I suppose there were so many people who had our back and who didn’t care, nothing strange happened.

Gerhard thought that their relatively positive experiences in Jaco's residence were due to the other residents perceiving them to act like straight guys:

Gerhard: I honestly think the entire experience in his res was helped a lot by the fact that we are both tall. Like, I hate the word, but 'straight acting' gay guys. Because most heterosexual men are, when they are confronted in my opinion, men who are very outwardly gay, or flamboyant, not to be mean or anything, they tend to move against it. Because they are not comfortable with that. Cos that is, that is the stereotype and they aren't comfortable with a stereotype.

Gerhard's explanation is borne out by research that indicates that gender belief systems and norms play a critical role in explaining the differing attitudes towards same-sex relationships (Davies 2004). Hegemonic masculinity is considered to be a normative structure which dictates a specific set of values, and does not allow any exceptions (Hearn and Morrell 2012, 4; Sonnekus 2013, 24). Negative reactions toward gay men are therefore related to the extent to which they violate gender norms. Gay men who are perceived as acting 'straight' may have an easier time because they, unlike feminine gay men, only violate the heterosexual attraction 
norm and not the norm regarding proper masculine behaviour (Glick et al. 2007; Skidmore, Linsenmeier and Bailey 2006, 692).

Michelle and Allison believed that generally university residences were not same-sex couple friendly and that their own positive experience was a surprising exception which was due to their 'luck' of having 'a super liberal super accepting management that year'. They further explained:

Michelle: A lot of couples have had problems. I think it is actually like I've never had problems in my res and that is completely contributed to that res. And I think they are wonderful and I will forever say that they are wonderful but it is crazy to think that it was just because they are wonderful people that I had a nice experience... I remember in my first year like the very first day our like prim said, 'Listen some people might be gay, some people might discover their sexualities later you know, whatever the case may be everyone is welcome here and that is that'. And ja, that was really what it was. That was kind of the rule. But if a more conservative person who gets into that management position can just as easily say no homo.

Allison: Yes what if there's a 'you' [referring to Michelle] somewhere out there in a crappy res.

Michelle: A crappy res, then sorry for you. You're just going to have to not be gay now.

These participants' accounts are similar to the findings of Evans and Broido (2002) who found that LGBT students differed in their experience of residence environments, even though homophobia was not necessarily expressed openly. Our participants appeared to experience homophobia and heterosexism in nuanced and indirect ways in residences, but tended to view residence environments as positive if negative acts were minimal and/or not overtly expressed.

\section{(iii) Christian religion groupings}

Many of the participants had negative perspectives and experiences with regards to interactions with students who belonged to religious societies or groups on campus. They often experienced these students as exhibiting attitudes and behaviours which reflected 'love the sinner, hate the sin' or 'pray the gay away' ideas. Both Michelle and Allison had experiences of religious individuals wanting to 'convert you', and 'be your friend and come and save you'. Bob, who had been a member of a religious society, has been told that 'it's an abomination (to be gay), and you're going to hell'. Bob expanded on his experiences:

Bob: $\quad$ Initially it was enjoyable. Uhm, you know? Cause people didn’t know. And I kept my sexuality very private. But you know, word gets out and people just started to ignore me. And they would just, like, not speak to me, not want anything to do with me and uhm, you know, you kind of put two and two together and then you're just 
basically ostracised. Where uhm, I have like one or two people who would be willing to talk to me before and after a service, a church service. Uhm and the rest of them just wouldn't, so, and it happened regularly.

Nadine had discussions with all the religious societies on campus to find out their position regarding LGBT people:

Nadine: We had annual conversations with all the societies once a year and one of the things I was asked was, 'do you mind asking the church societies who are okay with gay members?’ Because there are gay people that would like to join the church.

Svedlana: It doesn't mean because you are gay you can’t be religious.

Nadine: Exactly! They want that space but they don’t have it. And um, so I was actually in conversation with each and every church society just as a question from a request from my society, 'Would you be okay with ...' and none of them said 'by all means!' They said, 'That's okay, but we would expect a lifestyle change'. 'Anyone is welcome in our church. The thing they must realise is what they are doing is sin.' Every single one of them.

Our participants indicated that some LGBT people do have a need to belong to a religious grouping or society but that they were not welcomed when they openly lived their sexual orientation with a same sex partner. This is similar to what has been found in other studies that have investigated the role of religion in the attitudes of students towards LGBT individuals (e.g., Olson, Cadge and Harrison 2006, 353; Rowatt et al. 2006, 404; Arndt 2004). LBGT students usually meet with opposition from church societies and religious affiliations (Killelea McEntarfer 2011; Reygan and Moane 2014, 306), particularly mainstream denominations of Christianity which reject non-normative sexual and gender identities and orientations (Reygan and Moane 2014).

\section{(iv) The LGBT society}

Lastly, we were struck by how often the local student LGBT society was referred to in the couples' responses. It was clear that this organisation played an important role in LGBT students' lives which in itself is significant. According to the participants, the society offered supportive 'coming out' programmes and social events, and provided opportunities to meet other LGBT students. In their view, the organisation was an important resource for especially younger LGB students who were new to the campus. Jaco and Gerhard met through one of the society's annual social functions. Their explanation of the role of the society was echoed by all the participants: 
Gerhard: Lesbigay creates the prime opportunity to potentially meet people, actually in a safeish environment.

Jaco: $\quad$ They made me feel very comfortable about like, 'Just relax, its fine', just chat to people and I think that actually helped me a lot with, uh, accepting myself.

Svedlana: It's made many of our friends feel a lot more comfortable because they can be openly gay here. It's sort of a safe zone. You see everyone around you and they are not judging... Its people you can associate with.

Although all the participants were very appreciative of the support and safety which the society offered, they also mentioned, unprompted, that the society and the small LGBT community was not always experienced as safe and supporting. They tend to associate the society events with 'superficial interactions where people were not interested in getting to know you but rather to get into your pants', as well as 'bitchy' in-group gossip and conflicts. Many of our participants indicated that they were therefore no longer closely involved with the society. The specific ingroup interactional climate was attributed to the small number of LGBT partners which resulted in a community where members, at different times, shared romantic partners. Alison and Michelle expressed this as follows:

Allison: Stellenbosch is really small, so if you sleep with two people you've slept with everyone in Stellenbosch.

Michelle: That probably sums up ninety percent of the conflict in the gay community.

LGBT societies are considered beneficial as they help to promote a support structure for LGBT students in environments where they may feel alienated or even marginalised (Killelea McEntarfer 2011). LeBeau and Jellison (2009) further suggest that in order for LGBT individuals to have a positive lesbian/gay identity and psychological well-being, involvement in the gay community is imperative. It seems, however, that the negative interactional components which caused our respondents to distance themselves from the society were also found in other gay societies and communities (Holt 2011; LeBeau and Jellison 2009). The gay men in Holt's $(2011,865)$ study, for example, experienced the conflict in their gay community as pathological and opted to stay away from community interactions or events. Furthermore, Fox and Ore (2010, 632) argue that historically queer spaces often fail to include diversity. These authors contend that in an exclusive LGBT society's attempts to challenge oppression and create a liberating group for LGBT individuals free from homophobia, they could also unwittingly contribute to the entrenchment of patriarchal discourses by excluding others, more specifically non-LGBT individuals. Killelea McEntarfer (2011, 329) suggests that LGBT groups or student societies should create partnerships and work with other student groups on 
campus to create an inclusive environment.

\section{'Walking on eggshells to not offend people': Constant monitoring and behaviour regulation}

Given the ambiguity of the campus environment, it is understandable that all the couples' accounts indicated that they were always anticipating the possibility of stigmatisation or harassment in public spaces. They were constantly vigilant and scanned their environments for possible negative responses from other people when they were out in public as a couple. David articulated it as follows:

David: $\quad$ This is an open society; you have a lot of support, but be careful .... So, although I feel secure, I have to physically be cautious and I think maybe it's sort of like this constant, like, front that I am ready to have when, you know, that I just need to get defensive as soon as somebody actually starts attacking me.

Furthermore, they monitored and modified their couple behaviour to fit a specific environment and to avoid negative reactions. Gerhard, for example, said that he would like to show his affection for Jaco in public, but felt restrained in this regard - often by Jaco's reluctance to 'draw attention to them'. Gerhard and Jaco agreed that it is a source of tension in their relationship as Gerhard was more inclined than Jaco to demonstrate their relationship status in public. They explained it as follows:

Gerhard: Lingering homophobia, resentment, strange looks. Uhm, strange comments. Uhm not that it actually would happen. But it's just I would rather prefer it not to happen. It's just being creative about it I suppose. I'd rather have it not happen. Than have it happen and have to handle it. Because I would be capable, we would both be capable of handling it. But I think we both, more him than myself, rather have it not happen at all, just to avoid tension.

Jaco: Well PDA [public display of affection] is kind of a thing we don't exactly see eye to eye. Because he feels that I don't, I want to like hold his hand in front of my old friends. I don't know, I just don't like the attention I get from it ... I can honestly say I've never had any bad experiences of people calling me out.

Gerhard: No, I honestly, don’t think they would.

Jaco: $\quad$ I think most people don't really care all that much.

Gerhard: Yeah, they might not care. But I'm not really intimidated. But I actually am. Sometimes. But, um, I do. For instance today, I walked past a couple on the Rooiplein, um, who, met each other, had a quick little make-out session and then went their separate ways. And I can’t do that with him ...

Gerhard continued to explain that they avoided physical touch when he and Jaco were together 
and Jaco saw old friends or people from his residence.

Gerhard: Ja, and when he would meet people. Um, or spot people or um, looked like they either were from his res or in his res or people that he physically knows. Like the typical Dagbreek kind of guy. Um, and if we were holding hands he would let go .... Um, but, yeah, generally when there's people around that we both recognise. Well that he recognises we tend to avoid all contact.

James shared Jaco's reluctance to draw attention to him and Max:

James: $\quad$ Sometimes I don’t like PDA because I just don’t like drawing attention to us. Especially the fact that we're gay. But, I mean we do hold hands. It's nice.

Max: We don't pretend that we're something we not. We don't pretend, 'ooh we are friends'.

Similar to the findings in other studies (e.g., Waitt and Gorman-Murray 2006) our participants perceived their environment as heteronormative and had designated spaces where they felt they could be themselves, show public displays of affection with a partner, and have a break from self-monitoring behaviour. David's and Bob's accounts also indicate that they minimised the possibility of homonegative experiences by selecting where they publicly conduct their relationship:

David: If we had to go to ' $X$ ' [a popular student pub] for example, we would not be able to hold hands, we wouldn't be able to do anything without having that fear and that very relevant fear that somebody will come up to you and beat the shit out of you for like being gay or whatever. So it definitely does depend on the area. I would definitely never go to a place like ' $\mathrm{X}$ 's and be affectionate or anything, whereas around the BA building, for example, I would be completely open to doing that.

Bob: I think another thing we need to add here is that on campus we aren't overtly affectionate. Um, you know, we were both initially very nervous about public displays of affection. Um, you know the consequences, so if we kiss it's a light peck. Or it's a very basic kiss. We hold hands. They're very small things .... Not like some of the irritating couples do when you pass you just hear slurping sounds and sucking face and going bonkers. We are reserved. ...When it comes to being in a relationship. You don't have to show the world that you are in a relationship.

David: $\quad$ So we kind of keep the affection for ourselves. It's more a choice.

Bob: $\quad$ Yeah, it's not like we are forced to do it or something.

Piper said that they generally did not experience homonegative responses on campus, but she agreed with Alex that this was due to their avoidance of potentially negative contexts. Similarly, Alison and Michelle described how they avoid uncomfortable social situations by referring to each other as 'my friend' when speaking to strangers during brief and superficial interactions. 
Alison explained:

Alison: Because it's not worth it to go and say 'my girlfriend' cause then it starts this whole issue with the cashier person and they ask questions and look at you and are rude to you. And they give you a kind of incredulous look .... So basically we gotta tip toe. Walk on egg shells kind of a thing. Make sure we don't offend people. I don't know, we are very much ... I don't have the activist gene.

These two lesbian couples also thought that they were not exposed to 'outright hatred', because they 'don't look like dykes'. People often believed that they were 'best friends holding hands' or that they 'look like sisters'. Michelle described herself as being a 'feminine' lesbian, and thought that her fellow students were 'okay' with her 'gayness' because she did not 'intimidate' them. Michelle also describes that she thinks that 'for more masculine girls it's a bit harder'. Alex and Piper describe the stereotypical lesbian as a 'butch' woman who has 'short hair', wears 'wife-beater shirts' and has 'tattoos'. These reports reflect elements of the heteronormative environment these couples find themselves in. 'Feminine' lesbians seem to be accepted more readily, because they conform, to a certain extent, to the heteronormative gender expectations of what a woman is supposed to look like. They are also less visible than stereotypical ‘butch’ lesbians.

Our respondents' stigma consciousness and their attendant regulation of public behaviour is similar to findings in other studies that have found that these mechanisms serve important self-protection functions (e.g., Dewaele, Van Houtte, Cox and Vincke 2013; Lasser and Tharinger 2003; Myrdahl 2011, 143; Pinel, Warner and Chua 2005, 486). These studies indicate that lesbian, gay and bisexual people make careful and planned decisions about whether or not to disclose their sexual orientation which Lasser and Tharinger $(2003,237)$ termed 'visibility management'. Visibility management is defined as the process of regulating the exposure of one's sexual orientation in many different social settings in order to avoid homonegative reactions or awkward situations (Lasser, Ryser and Price 2010, 416; Lasser and Tharinger 2003, 237).

Dewaele et al. (2013, 687) propose that visibility management is a conscious or unconscious mechanism to cope with ambiguous social environments. These authors also point out that LGBT people's acceptance of the possibility of stigma and avoidance of homophobic interactions by regulating their visibility, may function as both an adaptive and non-adaptive coping response. It may protect a person against the experience of rejection or negativity. Conversely it may hamper pro-active actions and a person claiming her/his rights to equal treatment. Moreover, according to Meyer’s (2003) theory of minority stress, the need for same- 
sex couples to manage stigma responses is an on-going minority stressor. This kind of minority stressor impacts negatively on the mental health of LGBT people and is often related to higher levels of internal stress (e.g., self-acceptance difficulties) and external stress (e.g., acts of discrimination) (Mohr and Daly 2008, 990).

\section{CONCLUSION AND RECOMMENDATIONS}

Although the university at which we conducted our study strives to encourage inclusivity, and our participants acknowledged encouraging signs of a changing campus climate towards the acceptance of same-sex relationships, our findings indicate that more needs to be done to reach the ideal of a general campus environment where same-sex couples can take an accepting environment for granted. Concerted efforts are required to make all campus spaces LGBT friendly. We agree with authors like Poynter and Washington $(2005,44)$ that senior administrative staff and student affairs administrators should accept the major responsibility for leading and/or encouraging transforming initiatives with regards to LGBT students. They should thus take on social advocacy roles that will disrupt and change the implicit heteronormative assumptions which imbue the socio-spatial settings on campus. Roper (2005, 86) advises these key administrators 'to develop, articulate, live, and lead by an educational philosophy that promotes campus wide awareness and support for LGBT students'. University management and administrators specifically need to participate and engage in LGBT events, and actively contribute to make this student body and their needs audible and visible by using a variety of university forums. However, our impression is that currently the local LGBT society carries the unfair and major burden of such social advocacy for LGBT issues, as well as offering support to LGBT students.

Research (e.g. Evans and Broido 2002; Messinger 2002) on overseas campuses has identified mechanisms that contribute to a welcoming LGBT environment. University diversity management could therefore investigate the relevance of these mechanisms for the campus of study. For example, environments where LGBT issues and challenges were integrated in the curriculum were experienced as the most supportive by LGBT students (Evans and Broido 2002). Furthermore, Evans and Broido (2002) identified mechanisms that specifically assist towards more positive resident environments. These include residence staff members actively challenging homophobic behavior, programmes to sensitise residents about LGBT issues, and visible gestures and symbols of support in residences and living spaces.

We indicated earlier that our sampling challenges that resulted in a limited homogenous sample of white, senior students highlight (i) the lack of institutional knowledge about LGBT 
students at Stellenbosch University, (ii) as well as lack of access points. This makes it difficult to reach these students and thus ascertain and address their challenges and well-being needs at this university. If the university is serious about its policy to offer an inclusive and welcoming environment to LGBT students, we want to argue that it cannot do so unless it generates more knowledge about its LGBT student body. Moreover, not pursuing such knowledge may be construed as assuming students' heterosexuality which may be the most damaging position to be taken by university management. The same kind of pro-active identification, outreach and support policies that have been developed to identify, access, track and support other marginalized and minority students (e.g. black students and students with disabilities), should therefore also be extended to LGBT students (Longerbeam et al. 2007). We particularly need information about new and undergraduate LGBT students who may find the ambiguous campus environment particularly challenging.

\section{ACKNOWLEDGEMENTS}

Our thanks to the participant couples who were so willing and open to share their experiences with us.

\section{NOTE}

1. Please note that although our study focused on lesbian and gay couples, we use the term LGBT where we make use of literature sources that use this encompassing term.

\section{REFERENCES}

Arndt, M. 2004. Attitudes towards lesbians and gay men: A university study. Master's dissertation. Rand Afrikaans University, Johannesburg, South Africa. https://ujdigispace.uj.ac.za/bitstream/ handle/10210/1403/Mastersresearch.pdf?sequence $=2$

Avery, A., J. Chase, L. Johansson, S. Litvak, D. Montero and M. Wydra. 2007. America's changing attitudes toward homosexuality, civil unions, and same-gender marriage: 1977-2004. Social Work 52(1): 71-79. doi:10.1093/sw/52.1.71.

Blackwell, C. W., J. L. Ricks and S. F. Dziegielewski. 2005. Discrimination of gays and lesbians: A social justice perspective. Journal of Health \& Social Policy 19(4): 27-43. doi:10.1300/J045v19n04_02.

Braun, B. and V. Clarke. 2006. Using thematic analysis in psychology. Qualitative Research in Psychology 3(2): 77-101. doi:10.1191/1478088706qp063oa.

Brickell, Chris. 2000. Heroes and invaders: Gay and lesbian pride parades and the public/private distinction in New Zealand media accounts. Gender, Place and Culture: A Journal of Feminist Geography 7(2): 163-178. doi.org/10.1080/713668868.

Bryman, A. 2008. Social research methods. 4th ed. Oxford, England: Oxford University Press.

Butler, A. H., A. H. Alpaslan, J. Strümpher and G. Astbury. 2008. Gay and lesbian youth experiences of homophobia in South African secondary education. Journal of Gay and Lesbian Issues in Education 1(2): 3-28. doi:10.1300/J367v01n02_02.

Camilleri, P. and M. Ryan. 2006. Social work students' attitudes toward homosexuality and their 
knowledge and attitudes toward homosexual parenting as an alternative family unit: An Australian study. Social Work Education 25(3): 288-304. doi:10.1080/02615470600565244.

Collins, W. A. 2003. More than myth: The developmental significance of romantic relationships during adolescence. Journal of Research on Adolescence 13(1): 1-24. doi:10.1111/1532-7795.1301001.

Connell, R. W. and J. W. Messerschmidt. 2005. Hegemonic masculinity: Rethinking the concept. Gender and Society 19(6): 829-859. doi:10.1177/0891243205278639.

Connolly, C. M. 2006. A feminist perspective of resilience in lesbian couples. Journal of Feminist Family Therapy 18(1): 137-162. doi:10.1300/J086v18n01_06.

Davies, M. 2004. Correlates of negative attitudes toward gay men: Sexism, male role norms, and male sexuality. The Journal of Sex Research 41(3): 259-266. doi:10.1080/00224490409552233.

Dewaele, A., M. Van Houtte, N. Cox and J. Vincke. 2013. From coming out to visibility management - A new perspective on coping with minority stressors in LGB youth in Flanders. Journal of Homosexuality 60(5): 685-710. doi:10.1080/00918369.2013.773818.

Eisikovits, Z. and C. Koren. 2010. Approaches to and outcomes of dyadic interview analysis. Qualitative Health Research 20(12): 1642-1655. doi: 10.1177/1049732310376520.

Ellis, S. J., C. Kitzinger and S. Wilkonson. 2003. Attitudes towards lesbians and gay men and support for lesbian and gay human rights among psychology students. Journal of Homosexuality 44(1): 121-138. doi:10.1300/J082v44n01_07.

Ellis, S. J. 2009. Diversity and inclusivity at university: A survey of the experiences of lesbian, gay, bisexual and trans (LGBT) students in the UK. Higher Education 57(6): 723-739. doi:10.1007/s10734-008-9172-y.

Evans, I. 2010. Stellenbosch University abuzz after student paper prints photo of gay kiss. The Christian Science Monitor. http://www.csmonitor.com/World/Global-News/2010/0820/ StellenboschUniversity-abuzz-after-student-paper-prints-photo-of-gay-kiss

Evans, N. J. and E. M. Broido. 2002. The experiences of lesbian and bisexual women in college residence halls. Journal of Lesbian Studies 6(3): 29-42. doi:10.1300/J155v06n03_04.

Ferreira, E. and R. Salvador. 2015. Lesbian collaborative web mapping: Disrupting heteronormativity in Portugal. Gender, Place \& Culture 22(7): 954-970. doi: 10.1080/0966369X.2014.917276.

Fox, C. O. and T. E. Ore. 2010. (Un)Covering normalized gender and race subjectivities in LGBT 'safe spaces'. Feminist Studies 36(3): 629-649. http://web.b.ebscohost.com.ez.sun.ac.za/ehost/ pdfviewer/pdfviewer?sid=778999d8-3731-483d-9633-c40e3cd791b9\%40sessionmgr110\&vid= 1\&hid $=107$

Gelbal, S. and V. Duyan. 2006. Attitudes of university students towards lesbians and gay men in Turkey. Sex Roles 55(7): 573-579. doi:10.1007/s11199-006-9112-1.

Glick, P., C. Gangl, S. Gibb, S. Klumpner and E. Weinberg. 2007. Defensive reactions to masculinity threat: More negative affect toward effeminate (but not masculine) gay men. Sex Roles 57(1): 5559. doi:10.1007/s11199-007-9195-3.

Graziano, K. J. 2004. Coming out on a South African university campus: Adaptations of gay men and lesbians. Society in Transition 35(2): 273-286. doi:10.1080/21528586.2004.10419119.

Gregson, N. and G. Rose. 2000. Taking Butler elsewhere: Performativities, spatialities and subjectivities. Environment and Planning D: Society and Space 18(4): 433-452. doi: $10.1068 / \mathrm{d} 232$.

Haralambos, M. and M. Holborn. 2008. Sociology: Themes and perspectives. 7th ed. Hammersmith, London: Collins.

Hearn, J. and R. Morrell. 2012. Reviewing hegemonic masculinities and men in Sweden and South Africa. Men and Masculinities 15(3) 3-10. doi:10.1177/1097184X11432111.

Hill, R. J. 2006. What's it like to be queer here? New Directions for Adult and Continuing Education 112: 7-16. doi:1 0.1002/ace. 
Holt, M. 2011. Gay men and ambivalence about 'gay community': From gay community attachment to personal communities. Culture, Health \& Sexuality 13(8): 857-871. doi:10.1080/13691058.2011.581390.

Hopwood, M. and J. Connors. 2002. Heterosexual attitudes to homosexuality: Homophobia at a rural Australian university. Journal of Gay \& Lesbian Social Services 14(2): 79-94. doi:10.1300/J041v14n02_07.

Hubbard, P. 2001. Sex zones: Intimacy, citizenship and public space. Sexualities 4(1): 51-71. http://sex.sagepub.com.ez.sun.ac.za/content/4/1/51.full.pdf+html

Killelea McEntarfer, H. 2011. 'Not going away': Approaches used by students, faculty, and staff members to create gay-straight alliances at three religiously affiliated universities. Journal of LGBT Youth 8(4): 309-331. doi:10.1080/19361653.2011.607623.

Kite, M. E. 2001. Changing times, changing gender roles: Who do we want women and men to be? In The handbook of the psychology of women and gender, ed. R. Unger, 215-227. New Your, NY: Wiley.

Lambert, E. G., L. A. Ventura, D. E. Hall and T. Cluse-Tolar. 2006. College students' views on gay and lesbian issues: Does education make a difference? Journal of Homosexuality 50(4): 1-30. doi:10.1300/J082v50n04_01.

Lasser, J., G. R. Ryser and L. R. Price. 2010. Development of a lesbian, gay, bisexual visibility management scale. Journal of Homosexuality 57(3): 415-428. doi:10.1080/00918360903543154.

Lasser, J. and D. Tharinger. 2003. Visibility management in school and beyond: A qualitative study of gay, lesbian, bisexual youth. Journal of Adolescence 26(2): 233-244. doi:10.1016/S01401971(02)00132-X.

LeBeau, R. T. and W. A. Jellison. 2009. Why get involved? Exploring gay and bisexual men's experience of the gay community. Journal of Homosexuality 56(1): 56-76. doi:10.1080/00918360802551522.

Lehmiller, J. J. and C. R. Agnew. 2006. Marginalized relationships: The impact of social disapproval on romantic relationship commitment. Personality and Social Psychology Bulletin 32(1): 40-51. doi:10.1177/0146167205278710.

Longerbeam, S. D., K. K. Inkelas, D. R. Johnson and Z. S. Lee. 2007. Lesbian, gay, and bisexual college student experiences: An exploratory study. Journal of College Student Development 48(2): 215230. http://ez.sun.ac.za/login?url=http://search.proquest.com/docview/195185250?accountid= 14049

Mellor, R., E. Slaymaker and J. Cleland. 2013. Recognizing and overcoming challenges of couple interview research. Qualitative Health Research 2310): 1399-1407. doi:10.1177/1049732313506963.

Meyer, I. H. 2003. Prejudice, social stress, and mental health in lesbian, gay, and bisexual populations: Conceptual issues and research evidence. Psychological Bulletin, 129(5): 674-697. doi:10.1037/0033-2909.129.5.674.

Messinger, L. 2002. Policy and practice: A holistic approach to addressing homophobia and heterosexism among social work students. Journal of Lesbian Studies 6(3-4): 121-132. doi:10.1300/J155v06n03_11.

Mohr, J. J. and C. A. Daly. 2008. Sexual minority stress and changes in relationship quality in same-sex couples. Journal of Social and Personal Relationships 25(6): 989-1007. doi:10.1177/0265407508100311.

Mongie, L. 2008. Gay (in)tolerance in the language of Stellenbosch students: A critical discourse analysis of campus news media. Master's dissertation. Stellenbosch University, Stellenbosch, South Africa.

Moya, P. M. L. 2001. 'Chicana feminism and postmodernist theory.' Signs: Journal of Women in Culture and Society 26(2): 441-483. http://signsjournal.org/ 
Mwaba, K. 2009. Attitudes and beliefs about homosexuality and same-sex marriage among a sample of South African students. Social Behaviour and Personality 37(6): 801-804. doi:10.2224/sbp.2009.37.6.801.

Myrdahl, T. M. 2011. Lesbian visibility and the politics of covering in women's basketball game spaces. Leisure Studies 30(2): 139-156. doi:10.1080/02614367.2010.513714.

October, H. 2006. Interaksie binne 'n heteroseksuele studentegemeenskap: Ervarings en persepsies van 'n geselekteerd groep homo- en biseksuele student. Master's dissertation. Stellenbosch University, Stellenbosch, South Africa.

Olson, L. R., W. Cadge and J. T. Harrison. 2006. Religion and public opinion about same-sex marriage. Social Science Quarterly 87(2): 340-360. doi:10.1111/j.1540-6237.2006.00384.x.

Pew Research Center. 2013. The global divide on homosexuality. http://www.pewglobal.org/files/ 2013/06/Pew-Global-Attitudes-Homosexuality-Report-FINAL-JUNE-4-2013.pdf

Pinel, E. C., L. R. Warner and P. P. Chua. 2005. Getting there is only half the battle: Stigma consciousness and maintaining diversity in higher education. Journal of Social Issues 61: 481506.

Poynter, K. and D. Washington. 2005. Multiple identities: Creating community on campus for LGBT students. New Directions for Student Services 2005 111: 41-47.

Rankin, S. R. 2003. Campus climate: For gay, lesbian, bisexual, and transgender people: A national perspective. New York: National Gay and Lesbian Task Force Policy Institute. http://www.the taskforce.org/static_html/downloads/reports/reports/CampusClimate.pdf

Rankin, S. R. 2005. Campus climates for sexual minorities. In Gender identity and sexual orientation: Research, policy, and personal perspectives: New directions for student services 111, ed. R. L. Sanlo, 17-24. San Francisco, California: Jossey-Bass.

Reygan, F. and G. Moane. 2014. Religious homophobia: The experiences of a sample of lesbian, gay, bisexual and transgender (LGBT) people in Ireland. Culture and Religion: An Interdisciplinary Journal 15(3): 298-312. doi:10.1080/14755610.2014.942329.

Rhode, D. L. 1990. Feminist critical theories. Stanford Law Review 42(3): 617-638. http://www.jstor. org.ez.sun.ac.za/stable/pdfplus/1228887.pdf

Roberts, B. and V. Reddy. 2008. Pride and prejudice: Public attitudes toward homosexuality. HSRC Review 6(4): 9-11. http://www.hsrc.ac.za/en/review

Roper, L. D. 2005. The role of senior student affairs officers in supporting LGBT students: Exploring the landscape of one's life. New Directions for Student Services (111): 81-88. http://web.b. ebscohost.com.ez.sun.ac.za/ehost/pdfviewer/pdfviewer?sid=3e072258-0602-44ec-bc5a-e98e3a 5eb3e\%40sessionmgr105\&vid=2\&hid $=115$

Rostosky, S. S., E. D. Riggle, B. E. Gray and R. L. Hatton. 2007. Minority stress experiences in committed same-sex couple relationships. Professional Psychology: Research and Practice 38(4): 392-400. doi:10.1037/0735-7028.38.4.392.

Rowatt, W. C., J. Tsang, J. Kelly, B. La Martina, M. McCullers and A. McKinley. 2006. Associations between religious personality dimensions and implicit homosexual prejudice. Journal of Scientific Study of Religion 45(3): 397-406. doi:10.1111/j.1468-5906.2006.00314.x.

Skidmore, W. C., J. A. W. Linsenmeier and J. M. Bailey. 2006. Gender nonconformity and psychological distress in lesbians and gay men. Archives of Sexual Behaviour 35(6): 685-697. doi:10.1007/s10508-006-9108-5.

Sonnekus, T. 2013. 'We're not faggots!': Masculinity, homosexuality and the representation of Afrikaner men who have sex with men in the film Skoonheid and online. South African Review of Sociology 44(1): 22-39. doi:10.1080/21528586.2013.784446.

Szymanski, D. M. 2005. A feminist approach to working with internalized heterosexism in lesbians. Journal of College Counselling 8(1): 74-85. doi:10.1002/j.2161-1882.2005.tb00074.x.

Taywaditep, K. J. 2002. Marginalization among the marginalized: Gay men’s anti-effeminacy attitudes. 
Journal of Homosexuality 42(1): 1-28. doi:10.1300/J082v42n01_01.

Tetreault, P. A., R. Fette, P. C. Meidlinger and D. Hope. 2013. Perceptions of campus climate by sexual minorities. Journal of Homosexuality 60(7): 947-964. doi:10.1080/00918369.2013.774874.

Waitt, G. R. and A. W. Gorman-Murray. 2006. Places of reconciliation: Gay, lesbian and transgender place-based belongings in a regional Australian centre. Annual conference of the Australian Sociological Association. Sociology for a mobile world, Perth, Australia. http://ro.uow.edu.au/ scipapers/3426/

Willig, C. 2013. Introducing qualitative research in psychology. McGraw-Hill Education (UK). 